Cómo citar este artículo en Chicago: Muñoz González, Diana M. "Prestar oído a lo indecible. La interpretación: entre hermenéutica y deconstrucción”. Escritos 29, no. 62 (2021): 33-55. doi: http://dx.doi.org/10.18566/escr.v29n62.a03

Fecha de recepción: 26.01 .2021

Fecha de aceptación: 01.03.2021

\title{
Prestar oído a lo indecible. La interpretación: entre hermenéutica y deconstrucción
}

\author{
Listening Carefully to the Unspeakable. \\ Interpretation: Between Hermeneutics and Deconstruction
}

Diana M. Muñoz González ${ }^{1}$

\begin{abstract}
RESUMEN
Haciendo de la obra poética de Paul Celan la ocasión para exhibir el modo en que la hermenéutica filosófica de Hans-Georg Gadamer opera en el encuentro dialógico que establece con los textos, este artículo reconstruye inicialmente la lectura gadameriana de algunos poemas de Paul Celan y, posteriormente, contrasta este enfoque interpretativo con el adoptado por el filósofo francés Jacques Derrida, representante de esa otra vertiente hermenéutica de inspiración heideggeriana conocida como deconstrucción. También lector y admirador de Celan, Derrida opone al principio hermenéutico de Gadamer, que persigue restituir la unidad de sentido del texto, el carácter abierto, secreto e indecibible del poema. Pese a sus diferencias, se trata, sin embargo, de mostrar en este artículo que en ambos casos se busca responder a una negatividad que recorre el poema, cuyo silencio elocuente interpela y moviliza la lectura que se desarrolla, empero, en dos direcciones: la hermenéutica y la deconstructiva, respectivamente. Prestar oído a esta negatividad, a lo inaudible del poema celaniano, se revela, pues, como el impulso común al que responden estos dos filósofos contemporáneos, gracias a lo cual sus enfoques se muestran más cercanos de lo que a primera vista suele pensarse.
\end{abstract}

Palabras clave: Hermenéutica; Deconstrucción; Hans-Georg Gadamer; Jacques Derrida; Paul Celan; Diálogo; Textualidad; Poema; Silencio; Oído interior.

\section{ABSTRACT}

The poetic work of Paul Celan provides an opportunity to display how Hans-Georg Gadamer's hermeneutics dialogues with texts. The article reconstructs Gadamer's reading of some of the poems of Celan and contrasts this interpretative approach to that of Jacques Derrida, representative of a trend of hermeneutics known as

1 Doctora en Filosofía por la Université Paris 8, Francia. Directora de la línea de énfasis en filosofía del Doctorado en Humanidades. Humanismo y Persona de la Universidad de San Buenaventura, Colombia. Correo electrónico: dmunoz@usbbog.edu.co. 
deconstruction and which is inspired by the philosophy of Martin Heidegger. Derrida, who is also reader and admirer of Celan, stresses the open, secret, and unspeakable nature of the poem in contrast to the hermeneutic principle of Gadamer that emphasizes the recovery of meaning. Despite the differences of both approaches, the article argues that they address some form of negativity within the poem, whose silence questions and motivates both readings, though they go in different directions. Being able to listen carefully to the negativity of the poem, to what is unspeakable within the poetic work of Celan, reveals itself as a common motivation in these contemporaneous philosophers, which turns out to make them look closer than they appear to be at first sight.

Keywords: Hermeneutics; Deconstruction; Hans-Georg Gadamer; Jacques Derrida; Paul Celan; Dialogue; Textuality; Poem; Silence; Inner Listening.

\section{Introducción}

$\mathrm{Q}$ uizá no haya una mejor manera de entender en qué consiste exactamente la hermenéutica en cuanto práctica filosófica que observando cómo opera en el terreno que le es más propio: el de la comprensión textual. Esta es la razón por la cual, en lo que sigue de este artículo, me ocuparé de la forma como Hans-Georg Gadamer se confronta con la poesía de Paul Celan. Será, en efecto, en ese "cuerpo a cuerpo" que el filósofo alemán entabla con esta obra poética, como la lectura gadameriana de Celan nos permitirá descubrir los lineamientos a los que obedece el ejercicio hermenéutico de comprensión e interpretación de los textos. Ahora bien, Celan será, además, el terreno sobre el cual se dibujará la tensión de la hermenéutica con otra forma de abordar la interpretación. Ciertamente, será Celan quien nos permita contrastar la hermenéutica de Gadamer, por un lado, con la deconstrucción de Derrida, por otro, en la medida en que cada uno de ellos desplegó sobre el poema celaniano un modo de comprender y de realizar el trabajo de lectura, que tanto los acerca como los aleja, en la manera que tienen de concebir el modo de ser del texto y, por ende, de realizar la tarea interpretativa que este impone.

Antes que nada, ¿por qué hacer intervenir a un tercero en este tête-à-tête entre el alemán Hans-Georg Gadamer y el francés Jacques Derrida? Sabido es que la relación entre el padre de la hermenéutica filosófica y el artífice de la deconstrucción fue bastante ambigua. En el escenario público los escasos encuentros que sostuvieron dejaron en el auditorio de especialistas una perdurable sensación de que en el terreno filosófico era más lo que los separaba que lo que podría reunirlos, no obstante ser considerados ambos continuadores, en algún sentido, del legado heideggeriano. En lo personal, por otro lado, parecía existir un profundo respeto y una mutua admiración; Gadamer dejaría saber de su temprano interés y aprecio por el trabajo del francés, mientras Derrida hablaría, incluso, de amistad. Él mismo describe su encuentro con Gadamer como unheimlich, término alemán que reconoce intraducible y que podría ser vertido con algún éxito con la fórmula de "extraña familiaridad". Sin embargo, es evidente que la relación filosófica entre ambos se mostró, cuando menos tirante, cuando más apática. Gadamer lamentó a menudo la dificultad de Derrida (sugeriría incluso su inaptitud) para el diálogo, experiencia que, como sabemos, constituye para el filósofo alemán la forma auténtica de comprensión. El francés, por su lado, no dejó de expresar su sospecha respecto de lo que consideraba el dispositivo "violento" del intercambio dialéctico, que, en cuanto tal, clausura de entrada la posibilidad de salir al encuentro de lo auténticamente otro del otro. Este desnivel profundo en sus maneras de concebir y practicar la filosofía fue lo que con seguridad llevó al sonado desencuentro en que para muchos se convirtió el rendezvous parisino de las dos figuras en 1981. 
Nuestro interés aquí no reside, empero, en discutir las razones que puedan explicar la dificultad, o incluso la imposibilidad, tal como algunos alegan, para que llegara a entablarse un auténtico debate entre estas dos figuras representativas de la filosofía llamada continental. Partimos más bien de que lo ocurrido entre ellos obedece, de esa extraña manera de la que habla Derrida, a una forma de diálogo y, más aún, que este diálogo acontece, como no puede sino ser, de un modo indirecto. No es, pues, bajo la forma de un inmediato cara a cara, sino, en cierto modo, de espaldas uno al otro, como el encuentro entre ambos llega a producirse. Será, entonces, por la vía de un tercero, que veremos discurrir tal encuentro. Un "tercero" que, no como uno más que se añade al duelo entre dos, sino como el lugar mismo de la posibilidad de tal duelo, viene a dar testimonio de la familiaridad entre Gadamer y Derrida: el poeta Paul Celan. ${ }^{2}$ En realidad, al plantear este puente, o más bien este rodeo, no hacemos más que prolongar el gesto explícito del mismo Derrida, quien, en un acto de homenaje póstumo a Gadamer en 2004 (veintitrés años después de la "fracasada" cita en París) convocara al poeta judeoalemán como el "lugar" en el cual se estaría llevando a cabo, desde hacía tiempo, y sin quizá saberlo ellos mismos, un encuentro entre ambos, aun si en vida del filósofo de la hermenéutica tal encuentro pareció no haber tenido efectivamente lugar.

La razón para esta particular escogencia tenía que ver, sin duda, con el hecho de que tanto él mismo como Gadamer se habían entregado, cada uno a su manera, a una lectura paciente y apasionada de la difícil obra celaniana. ${ }^{3}$ Esa simpatía compartida por el poeta del hermetismo, como se ha dado en llamar a Celan, en virtud del lenguaje críptico y a menudo impenetrable que caracteriza sus poemas, debía guardar algunas claves de lo que en el fondo unía a Gadamer y a Derrida. Así es como el poema celaniano se erige en el telón en el cual poder proyectar, recortadas, pero al fin niveladas sobre un mismo plano, sus respectivas siluetas como lectores. No obstante, sería ingenuo creer que Celan vendrá a limar las asperezas y allanar el terreno para un encuentro finalmente directo y frontal de sus respectivos enfoques interpretativos. Aunque Derrida reconoce méritos importantes a la lectura que hace Gadamer, por haber sabido preservar lo que el francés llama algo así como el misterio del poema celaniano, y por haber

2 De hecho, la exigente obra poética de Paul Celan ha sido objeto de interés para varios filósofos contemporáneos, entre quienes se cuenta especialmente Theodor W. Adorno. El filósofo de la escuela de Fráncfort, quien lanzara aquella célebre sentencia "Después de Auschwitz escribir poesía es un acto de barbarie", vuelve precisamente su mirada sobre la poesía celaniana, en la medida en que esta parece ofrecer resistencia al carácter perentorio de su dictamen. El que un poema como "Todesfuge" en que Celan es capaz de tratar con lo irrepresentable del horror de los campos de exterminio, sin por ello traicionar la negatividad absoluta del acontecimiento, resuena con la teoría estética desarrollada por Adorno en su obra tardía; cf. José A. Zamora, "Estética del horror: Negatividad y representación después de Auschwitz", Isegoría, n.o 23 (2000): 183-196. Por su parte, Celan también interpeló, y ¡de qué manera!, a Heidegger. Como recuerda Pablo Oyarzún, no ha cesado de ser motivo de especulación el contenido, nunca revelado, de la conversación sostenida entre el poeta judío y el pensador afiliado al partido nazi, en un encuentro personal que tuvo lugar en 1967 en la cabaña del filósofo luego de la guerra, al que Celan evoca en el poema "Todnauberg"; cf. Pablo Oyarzún, Entre Celan y Heidegger (Santiago de Chile: Metales Pesados, 2013). La relación epistolar y el mutuo interés que se profesaron el poeta y el filósofo a lo largo de varios años motiva también el trabajo de Hadrien France-Lanord, Paul Celan et Martin Heidegger: Le sens d'un dialogue (París: Fayard, 2004) dedicado a delinear el espacio del tenso y rico diálogo entre la poesía (celaniana) y la filosofía (heideggeriana).

3 Ante la reputada dificultad de la poesía de Celan, impenetrable para muchos de sus lectores, incluso los más avezados, el poeta ofrecía, como recuerda Amador Vega, el siguiente consejo: "Leer, leer una y otra vez; la comprensión llegará por sí sola". En cierto modo, se trata de un estar ahí, dispuestos, atentos, hasta que el poema se abra al lector. Nosotros diremos, con Gadamer y Derrida, hasta que su silencio finalmente hable; cf. Amador Vega, Tres poetas del exceso: La hermenéutica imposible en Eckhardt, Silesius y Celan (Barcelona: Fragmenta, 2011). 
evitado, por consiguiente, el peligro que acecha a toda lectura dogmática de querer clausurar las infinitas posibilidades de sentido que el texto poético alberga, a pesar de ello, decimos, el filósofo francés deja asomar su malestar. Derrida señala la incapacidad para la lectura, en clave hermenéutica, de aliarse verdaderamente con lo que podríamos llamar el silencio del poema.

Probablemente, Gadamer habría lamentado ser, de nuevo, objeto de un reproche injustificado de la parte de Derrida, considerando que él es el primero en llamar la atención sobre la ineludible responsabilidad que como lector le cabe de dejar callar al poema. Gadamer insiste en que como intérprete de Celan su deber ha sido dejar en suspenso la interpretación allí donde el poema le ha opuesto una insuperable resistencia. Como quiera, parece ser una preocupación común a ambos, como lectores de Celan, señalar los límites de la comprensión del poema, aun cuando esta preocupación no se vea formulada en términos lo suficientemente compartidos como para hablar de un posible acuerdo de base; cada uno parece entender de modo tan distinto esos límites que es precisamente en esta preocupación en que parece que se tocan, que, a la vez, sus respectivos enfoques de lectura se alejan profundamente. Tal distante cercanía, podemos añadir, concierne al importante papel que cada uno confiere a la escucha como parte fundamental del ejercicio de la lectura.

Esta importancia es sobre todo evidente en el caso de Gadamer, para quien leer un texto, sea este poético o no, supone la capacidad de dejarse interpelar y de responder al llamado que este nos dirige, llamado cuya fuerza nos obliga, precisamente, a ser todo oídos (expresión usual en Gadamer) para lo que este tiene para decirnos. No es así de claro en lo que respecta a Derrida. La escucha no sobresale, al menos a primera vista, en su reflexión acerca de la lectura, ella no ocupa un lugar explícito, en todo caso no en el mismo sentido de Gadamer, ya que para el francés no se trata, de ningún modo, de entablar con el texto un encuentro dialógico en el que aquel habla mientras el lector escucha. En realidad, cabría imaginar cierta resistencia por parte de Derrida a enfatizar la escucha como rasgo fundamental de su idea de lectura si se considera la denuncia que él hace de lo que considera el fonocentrismo propio del pensamiento occidental. No hay que olvidar, en efecto, su connotada tesis acerca del rebajamiento de la escritura, según la cual desde Sócrates la escritura se ha visto reducida a la condición secundaria, contingente y, en fin, accesoria respecto del habla. La escritura, sostiene Derrida, empleando los términos de la lingüística saussuriana, ha sido entendida como significante escrito de significante oral, es decir, se la ha concebido esencialmente como escritura fonética. Ahora bien, si tal rebajamiento se ha producido, esto es porque el ser, siguiendo a Heidegger, ha sido pensado en términos de presencia.

En efecto, el logocentrismo que determina el ser del ente como presencia es necesariamente solidario del fonocentrismo ("todo fonocentrismo es un logocentrismo", dice Derrida), ya que el privilegio acordado al habla y, por ende, a la escucha también, como contraparte de aquella (habla y escucha forman un "bucle cerrado"), descansa en ese modo de pensamiento que define el ser como ousia. Tal privilegio se refleja en el valor concedido a la experiencia de oírse hablar a uno mismo. Cuando se escucha la propia voz decir algo, sostiene Derrida, se tiene la impresión de que no hay distancia que separe lo dicho por la voz de la voz misma. Dicho de otra manera, se considera que el sentido está ya ahí, presente en la voz, es decir, que existe una "proximidad absoluta de la voz y del ser, de la voz y la idealidad del sentido". Aunque la distancia persista, ya que pese a su inmediatez la voz no es exactamente la cosa misma, esta impresión de inmediatez, de no distinción, de no exterioridad de la cosa respecto de la voz, lleva a atribuirle al habla una preeminencia ontológica respecto de la escritura, la cual, por su parte, está destinada a no ser sino 
letra muerta mientras la lectura no venga en su auxilio, restituyéndole su carácter originario de habla viva. Es, pues, en razón de esta ilusión de proximidad que suscita el habla, que la escritura ha terminado por ser rebajada a "significante de significante", grammé subvalorada respecto de phoné.

Así pues, es de suponer que se vuelva altamente sospechosa, por fono-logo-céntrica, cualquier pretensión de hacer de la escucha el modelo de una experiencia de lectura. ${ }^{4} \mathrm{Y}$ con todo, resulta posible decir que también para Derrida leer tiene en el fondo que ver con un cierto oír, si bien la lectura no es para él reproducción de un sentido preexistente en el texto, sino producción de escritura. Esto es, multiplicación de las diferencias que el texto mismo produce y que lo mantienen irresolublemente abierto; Derrida denomina différance esa producción incesante de efectos diferenciales de la escritura. Y aunque ese juego de diferencias al que debe librarse el lector, en la tarea de desmontar cualquier mecanismo que busque inhibir su incesante producción de diferencias, es él mismo un juego silencioso, un juego inaudible, jugarlo es dar cuenta de su silencio. Esto nos lleva a decir que, en efecto, la lectura es también, para el autor francés, en tanto abandono gozoso a este juego diferencial de la escritura, un ejercicio de escucha, si bien difícil, por no decir imposible, ya que se trata de escuchar lo que no se deja en absoluto decir, al menos no como presencia o sentido.

Aunque en general la lectura admite ser entendida en ambos casos como un ejercicio de escucha, esta aparente cercanía se vuelve problemática cuando se trata de leer el poema, en particular, el de Celan. Como veremos, tanto para Gadamer como para Derrida prestar oído atento al poema implica orientarse hacia aquello que se mantiene elusivo y se sustrae a la comprensión, aquello que resiste a su puesta en presencia, en fin, hacia lo que se sitúa al límite de lo legible. La insatisfacción expresada por Derrida a propósito de la lectura de Gadamer deja suponer, entonces, que difieren de forma importante en la manera de entender la tarea de escucha, en la respuesta que dan al silencio insondable del poema. La diferencia tendrá que ver con la forma en que, en últimas, entienden los límites de la lectura. ${ }^{5}$ En lo que sigue trataremos de identificar grosso modo los principales rasgos de la lectura que Gadamer, en primer lugar, luego Derrida, hacen de los poemas celanianos, esperando mostrar que en ambos casos se trata de dar cuenta de tales límites y de la tarea que frente a ellos asume la filosofía según sea esta de impronta hermenéutica o deconstructivista. De hecho, si nos preguntamos por qué Celan pudo atraer con tanta intensidad la atención de estos dos filósofos, por lo demás conocidos por su profundo interés por la literatura, la razón puede estar en la manera en que él mismo entendió su poesía. Celan se batía contra la imposibilidad de dar testimonio del horror de Auschwitz, horror que se hizo innombrable en un idioma alemán que con este acontecimiento había quedado completamente en ruinas. El problema de los límites de lo decible era, pues, el suyo también.

4 Jacques Derrida, De la grammatologie (París: Éditions de Minuit, 1967), 23.

5 Los conocidos estudios filológicos de Peter Szondi sobre Celan dan cuenta de la tensión, incluso conflicto, que esta obra poética suscita entre varios enfoques interpretativos posibles. Es cierto que, frente al carácter hermético de los poemas celanianos, el desafío para el lector que busca descifrarlos es bastante considerable, muchas veces oscilando entre atender solo a la lógica interna del poema o en servirse de las referencias biográficas que se encuentran dispersas en la obra misma para colmar aparentes vacíos. El trabajo de Szondi señala los problemas de elaborar una hermenéutica de la poesía de Celan; cf. Peter Szondi, Estudios sobre Celan (Madrid: Trotta, 2005). 


\section{Gadamer, lector de Celan}

De las varias ocasiones en las que el filósofo alemán se ocupó de Celan, el opúsculo ¿Quién soy yo y quién eres tú?, ${ }^{6}$ publicado en 1973, en que Gadamer hace un detallado comentario de la colección de poemas Cristal de aliento (Atemkristall), es tal vez el que puede brindarnos más elementos teóricos sobre la manera como entabla el diálogo con esta difícil obra poética y, en general, cómo procede una lectura hermenéutica. ${ }^{7}$ En el prólogo, Gadamer retoma la imagen que el mismo Celan empleara para describir sus poemas como "una botella arrojada al mar", para retratarse a sí mismo como una suerte de paseante a quien el azar ha arrojado a sus pies esa botella vagabunda, $y$ así forzarlo a convertirse en su inesperado destinatario. Si azar hubo en este encuentro, lo cierto es que una vez que se produjo su efecto pareció ineludible, ya que no dejó a Gadamer otra opción más que detenerse y responder, según dice, como ese "tú" a quien el poeta, sin saberlo, se dirigía directamente. En efecto, tal como la imagen celaniana lo sugiere, este hallazgo fortuito le ha impuesto a Gadamer una tarea a la que, según confiesa el mismo filósofo, ha consagrado una paciente y prolongada dedicación ("las presentes páginas, escribe, dan fe de una larga relación con estos versos”); esta tarea consiste, claro, en acceder al mensaje que tal botella porta consigo. Al presentarla así, Gadamer se muestra fiel a la actitud que define, como él recuerda en el epílogo a su comentario, a un lector hermenéuticamente sensible, esto es, la de quien "quiere entender a otro, que como oyente o lector quiere entender una manifestación verbal. Siempre es, pues, entender a un texto, entender este texto concreto". Pero ¿qué significa "entender" un poema?

Si bien ha empleado el término "mensaje" (Aussage), siguiendo seguramente el impulso de la imagen celaniana de la botella, Gadamer lo ha hecho de manera cautelosa, pues, como ha dejado saber más de una vez en varios de sus escritos al referirse al modo de ser del texto poético (tema que le interesó de forma recurrente), lo propio de este no es envolver bellamente en un atuendo de palabras un mensaje que bien podría, sin embargo, sobrevivir y exponerse completamente al desnudo. ${ }^{9}$ La indisociable relación que en un texto poético se produce entre contenido y forma entraña una unidad que solo este tipo de texto, "eminente", en palabras de Gadamer, exhibe plenamente: una unidad entre lo dicho y el decir. Por tanto, como lector de Celan que se plantea la tarea de entender-lo, Gadamer no buscará simplemente extraer lo dicho en sus poemas dejando de lado el decir mismo, sino, antes bien, su desafío como lector residirá en dar cuenta del carácter indisociable que reúne ambos aspectos.

6 Hans-Georg Gadamer, ¿Quién soy yo y quién eres tú? Comentario a "Cristal de aliento" de Paul Celan (Barcelona: Herder, 2001).

7 Remítase el lector al excelente libro de Robert Caner-Liese, Gadamer, lector de Celan (Barcelona: Herder, 2009), en que el autor se traza el propósito de servirse de la lectura gadameriana de Celan como puerta de entrada a una reflexión amplia y detallada acerca de la actitud hermenéutica de entrar en relación con el texto poético, experimentando esa suerte de herida que es la negatividad del poema a la que responde el esfuerzo (hermenéutico) de darle sentido.

8 Gadamer, ¿Quién soy yo y quién eres tú?, 149.

9 Recordemos que la distinción que el juicio de gusto establece entre los aspectos estéticos o formales de la obra, por un lado, y los aspectos extraestéticos o de contenido, por otro, es denominada por Gadamer "distinción estética"; y al modo de juzgar la obra de arte basado en esta distinción el filósofo lo llama "consciencia estética". Su reclamo frente a este modo de experimentar la obra de arte va dirigido a que la abstracción que el sujeto realiza al juzgar sobre su belleza, basando su juicio en los aspectos puramente estéticos de la obra, implica una actitud objetivante, que termina por negarle su pretensión de verdad al arte. 
Valga anotar que, aunque llegue a calificar su tarea como "desciframiento", Gadamer rápidamente advierte en contra de la mala impresión que este término pudiera suscitar, y que haría pensar erróneamente que emprende un ejercicio de mera decodificación, proponiéndose, entonces, dar con una suerte de clave secreta con la que Celan habría encriptado formalmente el mensaje contenido en su botella, para, una vez descubierta esta clave, revelarlo de forma abierta y transparente. En ningún momento, Gadamer pretende, y no parece decirlo por falsa modestia, ${ }^{10}$ haber comprendido lo que los poemas dicen, al menos no de un modo definitivo y acabado. Si el lector de su comentario, advierte el filósofo, esperara tal revelación, no tendría caso que siguiera leyendo, pues no es para un lector así, demasiado ingenuo o demasiado apresurado, que él está hablando. Gadamer nos hace sentir, al revés, que se dirige a un lector más bien curtido, alguien que como él haya transitado y experimentado por sí mismo la enorme dificultad de la obra de Celan, y que, por ende, no estaría fácilmente dispuesto a dar por concluida la tarea de comprensión, sino que más bien estaría listo para ofrecer objeciones a cualquier interpretación que quisiera dar por superadas, de manera definitiva, las dificultades que estos poemas sin cesar plantean. Gadamer nos hace parte del carácter provisorio y hasta experimental de su lectura de Celan, la cual, según escribe: “cree haber encontrado 'sentido' en estos trazos oscuros, no siempre un sentido inequívoco, no siempre un sentido 'pleno'; a menudo solo ha descifrado ciertos pasajes y ha planteado vagas hipótesis sobre cómo completar su propia comprensión (que no el texto)”. ${ }^{11}$

Llamativa "confesión" la que encierran estas líneas, en el sentido de que cualquier vacío que al final pudiera lamentarse, o hasta reprocharse a su lectura, es, en realidad, un vacío que solo atañe a la debilidad de su comprensión y no al texto poético mismo, que, en tanto tal, se basta enteramente, y no carece, por ende, de nada que pudiera hacerlo plenamente comprensible: "La palabra poética es 'ella misma' en el sentido de que no existe otra cosa, no existe nada en relación con lo cual pueda medirse". ${ }^{12}$ En otras palabras, allí donde el lector de Celan se topa con una limitación insuperable, esta, al fin y al cabo, parece comprometerlo más a él en su incapacidad para ponerse a la altura del texto que a este en su capacidad para portar un sentido, de modo que el fracaso, si acaso el término puede valer de un modo categórico, es suyo, como lector, en su intento por entender, y no del poema por una supuesta incapacidad para hablar. Si cabe pensar en un fracaso, este quizá llegue a residir en la indebida expectativa del lector de que el texto le comunique algo, si esto quiere decir que deje exhalar fuera de él su etéreo y transparente mensaje para que él simplemente lo incorpore.

Así pues, con todo y lo muy ardua que la tarea pueda revelarse, entender a Celan es algo a lo que ningún lector serio y comprometido de su obra puede renunciar. Por esta razón, Gadamer se lamenta por el abandono de esta urgente tarea que dice advertir entre los comentaristas y especialistas. A su juicio, ha faltado entre tales lectores la voluntad o querer comprender lo que el poeta dice, y en lugar de ello ha primado la convicción acerca de la naturaleza críptica y, como suele decirse, hermética de la poesía de este autor, habiéndose tomado esto como una especie de excusa para evitar emprender cualquier esfuerzo comprensivo, y así reducir la labor crítica a constatar la aparente "derrota" del poeta frente a la ineptitud de la palabra para decir lo que él desea expresar. Por más penetrantes y elaborados que sean, pues, los análisis que desde la crítica literaria se han hecho de la obra celaniana, para Gadamer sobresale en ellos la ausencia

10 "Respecto a la obra de Celan, admitir la incomprensión es en la mayoría de los casos un mandamiento de la honestidad científica”. Gadamer, ¿Quién soy yo y quién eres tú?, 131.

11 Gadamer, ¿Quién soy yo y quién eres tú?, 7 [cursivas mías].

12 Gadamer, ¿Quién soy yo y quién eres tú?, 115. 
de todo intento por "comprender" verdaderamente lo dicho por el poeta. Por otro lado, sin embargo, por más difícil y hasta imposible que esta se anuncie, no se trata tampoco para Gadamer de incurrir en la ingenuidad de creer que hay allí un sentido remotamente originario a la espera de ser descubierto plena y unívocamente una vez hayan sido despejadas las oscuridades, ambigüedades y sombras que lo ocultan a la vista del lector no avisado. La ambigüedad no es el obstáculo que debe ser superado, sino, por el contrario, la condición o el medio mismo en que tiene lugar la comprensión: "Antes bien, se trata del sentido de lo ambiguo e indeterminado que el poema ha removido y que no es coto abierto a la arbitrariedad y discreción del lector, sino objeto del esfuerzo hermenéutico que estos versos exigen". ${ }^{13}$

Es verdad que la gran ambigüedad de los poemas de Celan parece arrebatarlos irremisiblemente a la comprensión del lector, hasta el punto de llevar a algunos a abandonar tal esfuerzo comprensivo y a concentrarse en aspectos de índole más bien formal. Para no hablar de que tal oscuridad sirve de pretexto para la licencia que, según Gadamer, se toman indebidamente ciertos intérpretes de Celan al librarse sin freno a lecturas arbitrarias y caprichosas, en la medida en que, según parecen reclamar, no hay, después de todo, manera alguna de acceder a lo verdadera y unívocamente dicho por el poema, de suerte que a falta de tal punto de referencia objetivo cualquier interpretación es válida. Gadamer, evidentemente, no cede ante esa tentación relativista y, por el contrario, hablará con insistencia de la necesidad de un "control crítico" al que el lector debe someter su propia interpretación, manteniéndose siempre alerta ante la posibilidad, que a cada paso acecha, de extraviarse en la multiplicidad de matices evocados. Esto, dice el filósofo alemán, implica mantenerse fiel al principio hermenéutico de la "unidad de sentido", principio por el cual el poema ha de ser tratado como una "unidad lingüística" en la que las partes sean vistas como encadenadas unas a otras conformando una unidad de sentido que las engloba a todas sin residuo. Es a esta exigencia que desea hacer responder la lectura que él mismo lleva a cabo: restituir los poemas en su auténtica unidad. Con esto sugiere que aquellos lectores que se escudan en la ambigüedad de los poemas para producir lecturas a la medida de sus propias especulaciones enfrentarán tarde o temprano la resistencia del texto a ser comprendidos en su unidad.

Ahora bien, la pregunta que el filósofo encuentra necesario plantear es si acaso dicho control crítico impone al intérprete poseer cierta información particular que le inhiba de lanzar hipótesis infundadas. Efectivamente, a las lecturas demasiado libres o arriesgadas que parece propiciar la oscuridad de los poemas de Celan podría, al parecer, ponérseles límite si se conocieran algunos detalles esclarecedores acerca de aquello a lo que el poeta remitía exactamente con tal o cual palabra empleada, con tal o cual referencia histórica velada, o cierta información acerca del momento o las circunstancias a las que el poema se refiere implícitamente. Gadamer reconoce, realmente, lo útil que le resultó en cierta ocasión conocer a través de Peter Szondi acerca de las circunstancias personales que rodearon la escritura de un poema de Celan, el cual se le había mostrado particularmente esquivo; tal información le había ayudado a encaminar mejor su interpretación y arrojar alguna claridad donde antes no la había visto. No obstante, Gadamer se pregunta si acaso esta información le había sido real y absolutamente necesaria, y si acaso el hecho de no poseerla habría impedido cualquier intento comprensivo exitoso de su parte. Dejando de lado lo anecdótico del asunto, él se plantea un problema mayor acerca de cuánto y, sobre todo, qué tendría que saber alguien para ser un "lector ideal" de estos poemas. Se refiere, por supuesto, a lo que debería saber por fuera o independiente de lo que el poema mismo le ofrece, algo así como un complemento necesario para que este le resulte plenamente diciente. Y la respuesta que ofrece no podría

13 Gadamer, ¿Quién soy yo y quién eres tú?, 111. 
ser más contundente: "No hay por qué saber nada privado o efímero. Y aunque se sepa, hay que hacer abstracción de tal saber y pensar únicamente en lo que el poema sabe”. ${ }^{14}$

Efectivamente, a lo largo del epílogo del libro mencionado, Gadamer nos pone sobre aviso acerca del peligro que puede representar para nuestra comprensión el hecho de tener o querer tener información "complementaria" (si queremos llamarla de algún modo) al poema, creyendo con ello disponer de los medios para fijar sin equívoco su sentido. Contrario a lo que se persigue, esta pretensión impediría, precisamente, comprender, esto es, atender a lo que por sí mismo el poema pretende y puede decir. Así pues, cuando Gadamer hace algunas consideraciones acerca de la distancia insalvable que, en términos culturales, lo separa de Celan, cuya obra, como se sabe, está impregnada de referencias, en extremo cultas, a costumbres, textos y tradiciones judíos completamente ajenos a lectores que, como Gadamer, provienen de otros horizontes y tradiciones, el filósofo concluye que esta distancia no debe ser tenida por un obstáculo para la comprensión como algunos pensarían, un obstáculo que, además, fuera posible superar mediante la adquisición de cierto conocimiento sobre esas materias. Si un intérprete juzgara que está desprovisto de información crucial y necesaria no contenida en el texto, y que esta carencia es la que le impide penetrar con seguridad y corrección en el verdadero sentido de los poemas, y así darse acríticamente a la tarea de recoger esta información, pone en grave riesgo su tarea interpretativa. En realidad, lejos de imposibilitarle la comprensión, esta distancia la favorece en gran medida. El riesgo para la lectura sería mayor, en cambio, si existiera una gran cercanía entre el autor y el lector, ya que este tendería a convertir la obra en mera prolongación de la biografía del autor y a reducir su comprensión a un intento, seguramente improbable y en todo caso improductivo, de congenialidad: "Quien no vaya más allá de lo que el poeta podría también decir sin recurrir a la poesía no entiende lo suficiente”. ${ }^{15}$

Así pues, aunque Gadamer parece admitir que conocer ciertos detalles acerca de las circunstancias biográficas o culturales que hayan podido marcar el nacimiento de una obra en particular puede ser algo eventualmente útil al lector, para optar con mayor criterio por una posibilidad interpretativa en lugar de otra, en el conjunto de su reflexión acerca de la conveniencia de poseer tal información pesa más, a la postre, la consciencia del peligro que esta entraña para la lectura. Esta información puede convertirse fácilmente en un obstáculo para atender al texto en su propia capacidad para decir algo por sí mismo, más allá o independiente de las circunstancias en que haya sido concebido, producido o pretendido por su autor. Algunos de los ejemplos que ofrece nos resultan particularmente interesantes por la inversión que gracias a ellos Gadamer le da al problema acerca de cuánto necesita saber el lector ideal para entender el poema; cuánto, se sobreentiende, que no esté dicho en el poema mismo. En realidad, para Gadamer no será tanto lo que el lector deba traer de fuera para esclarecer de modo más certero el sentido del texto como lo que desde el texto mismo, desde dentro de él, por así decir, debe lograr entender, para luego sí saber qué le conviene o no traer de fuera como información complementaria que eventualmente sea útil para encaminar su lectura.

Así, por ejemplo, descarta la relevancia que tendría para la labor del lector conocer versiones anteriores de un poema. Ciertamente, no es del todo evidente que tener acceso a versiones o estudios preliminares de un poema (fortuna que el mismo Gadamer dice haber tenido con algunos poemas de Celan) sea un recurso hermenéutico útil. Podría pensarse que sí lo es, en la medida en que seguir los cambios que el

14 Gadamer, ¿Quién soy yo y quién eres tú?, 128.

15 Gadamer, ¿Quién soy yo y quién eres tú?, 118. 
poeta hizo en la escogencia de una palabra, en el orden de la composición, etc., en contraste con su versión final, le permitiría al lector extraer de allí elementos para lanzar hipótesis más acertadas acerca del sentido que cabría darle al poema. Pero la creencia en su utilidad se basa en pensar que tales cambios son algo así como las huellas dejadas inconscientemente por el autor en su búsqueda progresiva de los medios más adecuados para dar expresión a su verdadera intención, huellas sobre las que el lector puede a su turno transitar, hasta llegar a ver él también el momento en que cristalizó el sentido, el momento en el que, al no haber introducido más cambios, el autor habría creído llegar a una composición lo más perfecta posible, en función de lo que buscaba paulatinamente expresar de modo cada vez más acabado. Sin embargo, lo que Gadamer hace notar es que el lector que tuviera acceso a estas versiones anteriores no aseguraría con esto criterio alguno para juzgar sobre la razón de ser de estos cambios, ni sobre el propósito de estos, si no tuviera ganada previamente una comprensión del texto "final", o, en otras palabras, si no fuera capaz de identificar retrospectivamente, por así decir, la necesidad que obligó al autor a hacer esas modificaciones. En otras palabras, no es tanto el autor, por cuenta de sus balbuceos o de su veleidosa creatividad, sino el poema mismo, en razón de su necesidad interna, el que exigió tales cambios en su configuración.

Conviene aquí mencionar la simpática anécdota relatada por Gadamer de cuando descubrió que por un problema de edición de la versión impresa a la cual él tuvo acceso había interpretado un poema de Celan que contenía un error en una palabra. El filósofo reconoce que temió por un momento que la pertinencia de su interpretación se viera seriamente comprometida por cuenta de ese error, pero concluye que, de hecho, el impacto no fue mayor. No descansando su interpretación en el sentido dado a cada una de las partes, sino, más bien al revés, determinándose el valor de estas por el todo unitario de sentido: el cambio en una palabra no supuso una dificultad insalvable en la medida en que no ponía en riesgo el conjunto. Y esto es debido a que una interpretación no busca dar cuenta de las partes aisladas, sino de la coherencia interna del poema, de su configuración o estructura como un todo. Por supuesto, esta situación anecdótica pone de presente el riesgo al que inevitablemente, según insiste Gadamer, se ve expuesta toda empresa interpretativa, de modo que es ese riesgo el que, por otro lado, le confiere su valor y alcance a la lectura: el riesgo de tener que tomar partido por una posibilidad de sentido y dejar muchas otras de lado: "El verdadero riesgo de la interpretación es decir cómo se entiende". ${ }^{16}$

De cualquier modo, es claro que el peligro que supone disponer de tales informaciones tiene que ver con no saber emplearlas en beneficio de la comprensión efectiva del texto y, por tanto, en impedir con ellas que el texto se valga por sí solo. Porque, en últimas, acceder al sentido de un poema no es privilegio de unos cuantos iniciados, de unos lectores eruditos que detentarían, por su refinado conocimiento en ciertas materias, las claves de desciframiento del sentido profundo del texto. Antes que un asunto de conocimiento o de saber, leer el poema nos demanda, según Gadamer, otra capacidad, que en cierto modo es más universal, aun cuando también mucho más escasa: saber escuchar:

Cuando y donde el poeta ha conseguido crear composiciones verbales que se sostienen por sí solas, el oído poético debería ser capaz de elevar cuanto es válido en ellas a un nivel de cierta claridad, con independencia y más allá de cualquier saber particular, y de aproximarse de este modo a la precisión que es el secreto a voces de esta poesía críptica. ${ }^{17}$

16 Gadamer, ¿Quién soy yo y quién eres tú?, 134.

17 Gadamer, ¿Quién soy yo y quién eres tú?, 113 [cursivas mías]. 
El lector ideal que Gadamer tiene en mente no es, pues, de ninguna manera, aquel que sabe mucho acerca de lo que rodea, desde fuera, al poema, y que busca servirse de ello para despejar la ambigüedad y fijar el sentido. Por el contrario, es aquel que sabe entrar en el poema y desde dentro logra determinar lo que eventualmente convendría o no saber, en aras de su comprensión, acerca de lo que viene de afuera. Esa capacidad es la que posee el lector con oído poético. Pero ¿qué oye ese oído poético? Lo que escucha es, claro está, lo poético del lenguaje, que no es otra cosa que la precisión de las palabras que componen el poema: "La precisión de lo dicho es lo que convierte el discurso en poema". ${ }^{18}$

La precisión a la hora de comprender el poema, solo alcanzada por el lector ideal a partir del propio poema y de los conocimientos que él mismo posee, sería desde luego el verdadero criterio. ${ }^{19}$

Con el apelativo de "precisión" (Richtigkeit) no se refiere al hecho de que las palabras en el texto poético posean un sentido unívoco e inapelable, en otras palabras, oírla no supone superar la ausencia de ambigüedad, de modo que a cada palabra pudiera adscribírsele un sentido único y evidente. De hecho, lo que solo el oído poético en su finura logra captar es más bien tal ambigüedad como resultado de un juego de resonancias simultáneas, en que unas sobresalen mientras otras pasan con sordina. El oído poético se asemeja a un entrenado oído musical en la medida en que parece captar simultáneamente varios registros sonoros, uno que resuena alto y otro que discurre a un nivel más bajo y menos audible, pero, sobre todo, capta la armonía que ambos registros conforman indisociablemente y que se perdería por completo si un registro no estuviera acompañado del otro, dado que es el juego entre ambos, su mutuo entrabamiento, el que confiere la profundidad y el volumen al conjunto.

Ahora bien, puesto que se trata de lenguaje, es decir, de palabras y no de meros sonidos o de notas musicales, es evidente que lo que el oído poético capta no es solo la realidad sonora de las palabras, sino también su significado. El oído poético capta la significación en su indisociable relación con el sonido, es decir, en el texto poético, una y otro, realidad sonora y valor semántico, avanzan de modo simultáneo e inseparable. Es verdad que Gadamer habla a veces de una "tensión entre sentido y sonoridad" en la medida en que el poema parece querer fijar nuestra atención sobre la sonoridad pura de sus palabras, cuya capacidad de fascinación es poderosa, y hacernos perder de vista su significación; y por otro lado busca lanzarnos más allá de las meras palabras hacia su pura e ideal significación y hacer olvidar los sonidos que mediante su materialidad la evocan. El oído poético se instala en medio de esta tensión sonoro-semántica, no para resolverla a favor de uno de los términos, sino para mostrar su carácter irresoluble. El oído capta la unidad de ambos movimientos:

Por muy oscura, llena de tensiones, frágil, agrietada y resquebrajada que sea la unidad inherente a la figura de sentido del discurso poético, la polivalencia de las palabras se fija mientras se establece el sentido del discurso y hace que un significado suene en toda su plenitud y el otro solo resuene..$^{20}$

En cierto modo, cabe decir que lo que escucha el oído poético es lo que Gadamer denomina la "sintaxis oculta" del poema o, como también dice en otras partes, un tejido de connotaciones (verbales). Lo que

18 Gadamer, ¿Quién soy yo y quién eres tú?, 114.

19 Gadamer, ¿Quién soy yo y quién eres tú?, 130.

20 Gadamer, ¿Quién soy yo y quién eres tú?, 114. 
cada palabra significa en el poema lo significa, no en virtud de su referencia a algo dado fuera del texto poético, una cierta realidad extra-textual a la cual reenviaría unívocamente, sino gracias a su lugar en la cadena lingüística (sonoro-semántica) en la cual se ubica en ese poema en particular. Es lo singular de ese lugar que ocupa lo que hace a la palabra y, por ende, a la cadena toda en la cual está inscrita, irreemplazable, intraducible, no parafraseable. Gadamer no cesa de insistir en que un poema llama a ser aprendido de memoria, como la única manera que él tiene de "estar ahí y de permanecer siempre ahi" ${ }^{21}$ Ningún cambio, en efecto, parece posible, sin perder con ello esa singular unidad de la cual depende lo que el poema como un todo unitario es capaz de decir. Dicho de otra manera, la palabra en el poema dice lo que dice por cuenta de su implicación en ese entramado particular.

En el poema, las palabras no nombran nada, al menos nada que exista fuera del poema mismo, sino que cada una es la marca de un lugar, de un lugar preciso que se produce como efecto del juego entre sonido y sentido que constituye la cadena textual que cada poema es. Por esto, Gadamer enfatiza lo siguiente en cierto momento de su lectura, a propósito del significado que la palabra piedra tendría en uno de los poemas de Celan que él comenta. Dice: “ojo, la 'piedra' de este poema!".22 Efectivamente, piedra significa lo que significa aquí. La auto-suficiencia de la palabra poética entendida como su capacidad para decir algo sin referencia a nada que le preexista o que la determine desde fuera es lo que Gadamer señala cuando afirma que el poema se sostiene por sí solo, no representa algo para lo cual pudiera haber otra palabra. ${ }^{23}$ De forma que lo que el oído poético escucha es, en últimas, ese lugar o, mejor aún, lo que escucha es el juego sonoro-semántico que produce como efecto ese lugar dentro del poema. De ahí, seguramente, el rechazo que, según recuerda Gadamer, mostraba Celan a la tentativa de pensar sus poemas en términos metafóricos, en la medida en que como unidades de sentido auto-subsistentes las metáforas podrían ser excluidas del entramado del discurso sin que aparentemente esto entrañara algún perjuicio esencial para el sentido de esta. En los poemas de Celan (como en realidad debe ser el caso en todo texto poético digno de ese título), es el todo el que comanda, determina y distribuye el valor de las partes que, en estricto sentido, solo existen en ese todo. Así pues, la precisión a cuya escucha se entrega el oído poético capta la necesidad del lugar en el que cae cada palabra dentro de la trama textual del poema.

Así como el poema es un pronunciado singular, un equilibrio incomparable e intraducible de sentido y sonoridad sobre el cual se levanta la lectura, también la palabra que interpreta es un pronunciado singular. No puede realizarse sin que el oído interno "oiga" cada palabra del texto interpretado. ${ }^{24}$

En verdad, no es fácil llegar a oír de este modo, ya que el oído poético busca una profundidad algo silenciosa, un silencio que acompaña a las palabras y al hacerlo les da su espesor significativo. ${ }^{25}$ El lector dotado de este oído hermenéuticamente sensible no pretende discernir con total limpieza y sin dejar residuo entre un nivel literal del texto que atendiera al aspecto puramente semántico de las palabras, y por

21 "Mais vous ne pouvez pas paraphraser un poème. Vous ne pouvez pas le remplacer! Par contre, vous pouvez l'apprendre par cœur afin qu'il sois là et demeure toujours là". Carsten Dutt, Herméneutique, esthétique, philosophie pratique: Dialogue avec Hans-Georg Gadamer (Québec: Les Editions Fides, 1998), 90.

22 Gadamer, ¿Quién soy yo y quién eres tú?, 133.

23 Gadamer, ¿Quién soy yo y quién eres tú?, 115.

24 Gadamer, ¿Quién soy yo y quién eres tú?, 134.

25 "Se trata, desde luego, de un oído sumamente sensible y, al mismo tiempo, de tareas que exigen toda la agudeza intelectual”. Gadamer, ¿Quién soy yo y quién eres tú?, 121 [cita modificada]. 
otro lado un nivel estrictamente formal de la pura sonoridad o composición sonora de las palabras. En realidad, si las palabras son ambiguas y logran evocar en permanencia múltiples sentidos, esto obedece, justamente, a ese juego sonoro-semántico en que están inscritas y a la profundidad de este. Cada palabra dice lo que dice en el poema, pero, al mismo tiempo, cada palabra pertenece u ocupa lugares distintos en otros textos que inevitablemente se verán evocados de forma subyacente por el poema al emplear esa palabra ya marcada por ellos. Cada palabra, por así decir, hace resonar el todo del lenguaje como un trasfondo respecto del cual destaca y que a la vez ella trae consigo (es diciente el empleo frecuente que hace Gadamer de la imagen de la "fuerza gravitacional" de las palabras), un fondo de significatividad en contraste con el cual, o por efecto de ese contraste, una palabra dice algo inédito en el poema concreto. En ello reside el carácter polisémico del poema. Al respecto, citemos las siguientes líneas de otro trabajo dedicado a Celan, bajo el título "Sentido y ocultación de sentido en Paul Celan", en las que Gadamer se refiere a la necesaria pluridimensionalidad del texto poético:

Esa dicción en "bloque" en la que las palabras aisladas, que suscitan determinadas representaciones se encuentran unas al lado de las otras, no significa que dichas palabras no puedan fundirse en una unidad de sentido. Lograr esta unidad, sin embargo, es una exigencia cuyo cumplimiento queda a arbitrio del lector. No es que el poeta oscurezca y oculte arbitrariamente la unidad de sentido. El poeta quiere precisamente revelar algo de ese modo y libera, mediante la conexión "en bloque", la pluridimensionalidad de las relaciones de sentido que en el unidimensional discurso cotidiano, dominado por la lógica, es mantenida a raya por la unidad práctica que crea la intención del discurso. ${ }^{26}$

Gadamer llama así a moverse en lo que él denomina varios planos de lectura, ya que hay, según sugiere, un nivel superficial o, según estas líneas, una lectura de tipo unidimensional, que sería aquella en la que las palabras son entendidas en el significado casi prefijado que estas tienen ya en con-textos habituales, independiente de su aparición en el poema, y un nivel más profundo, un segundo nivel, en el que las palabras significan algo nuevo, algo que solo en y por este texto pueden decir. Ambos planos ("planos de transposición") están entrelazados, por lo que un lector sagaz deberá desplazarse, sin extravío, entre uno $\mathrm{y}$ otro constantemente, si es que en verdad quiere entender el poema:

Un buen poema se distingue de un truco de prestidigitación, por muy misterioso que este sea, por el hecho de convencer tanto más de su precisión cuanto más penetra el lector en su estructura y en la técnica de sus efectos. Cuanto mayor es la precisión a la hora de comprender, tanto más llena de asociaciones y de sentido es la creación poética. ${ }^{27}$

Esta distinción entre lo que Gadamer llama un primer y un segundo plano pone claramente en perspectiva toda la discusión previa acerca de la necesidad, o incluso de la conveniencia, para comprender el poema, de conocer circunstancias adyacentes, tales como hechos de la vida privada del autor o referencias a acontecimientos o personajes particulares a los que este podría aludir. Todo esto constituye un primer plano del poema que solo ocasionalmente puede ayudar a iluminar su sentido, pero solo en un nivel superficial, ya que en ningún modo da cuenta de esa necesidad interna. ${ }^{28} \mathrm{Si}$ cabe pensar todo ese conocimiento como

26 Hans-Georg Gadamer, "Sentido y ocultación de sentido en Paul Celan”, en Poema y diálogo (Barcelona: Gedisa, 2004), 118.

27 Gadamer, ¿Quién soy yo y quién eres tú?, 121.

28 En este punto, es preciso reconocer una dificultad mayor en la posibilidad de trazar de manera tan tajante, como he 
una ayuda, es solo cuando la lectura se mueve en el primer plano. Conocer esos detalles puede servir para evitar un extravío en la interpretación, cuando el lector, dice Gadamer, está "absolutamente por cuenta propia", esto es, cuando por el hecho de no comprender el significado que las palabras tienen en con-textos diferentes, se las entiende demasiado libremente en el poema. Pero los poemas no deben ser oídos en un nivel superficial o primer plano, sino también en los diversos planos que lo componen simultáneamente. Casi habría que decir que leer es pasar permanentemente de un plano de escucha a otro y escuchar es jugar el juego del lenguaje en su infinita capacidad de evocación de significados.

Aquello para lo cual está afinado el oído poético tiene que ver, pues, con los efectos de sentido que se producen como resultado del juego sonoro-semántico entre los distintos planos que componen el texto; este oído se sitúa así entre un umbral de escucha habitual y un registro que excede, en cambio, el umbral de lo fácilmente audible, que atiende a lo casi inaudible para el oído poco sensible al juego del lenguaje poético. Por consiguiente, cuánto haya de saber el lector es un asunto que, como bien lo dice Gadamer, lo dirime enteramente la capacidad de su oído poético para no dejarse ensordecer con todo eso, frente a lo que el poema quiere hacer escuchar en su precisión. Efectivamente, el oído poético está constantemente amenazado en su capacidad de escucha por todo aquello que desde fuera del poema parece impedirle oír su precisión: "[El lector] debe saber tanto cuanto puede y debe aportar realmente a su lectura del poema, a su escucha del poema. Solo lo que soporta su oído poético sin ensordecer. Será a menudo bastante poco, pero seguirá siendo más que si es excesivo". ${ }^{29}$

Ahora bien, del mismo modo como no es ideal la situación de un lector que, por poseer cierta información de la que otros carecen, cree estar en condición de privilegio frente a la tarea de comprender el poema, así tampoco es cierto que el lector deba llegar desprovisto de expectativas, lo que de hecho es imposible en virtud del círculo de la comprensión (el círculo hermenéutico) en el que siempre estamos inmersos. Sin una serie de conocimientos previos que determinan la manera en que el lector comprenderá el poema o también lo que le resultará oscuro, nada puede interpelarlo. En otras palabras, cada lector debe poner de lo suyo cuando se acerca al poema, y esto supone comenzar por explicitar lo que resulta familiar en las palabras que el poema trae, pero que ahora, por cuenta del mismo poema, se ofrecen nuevas, extrañas, altisonantes, y obligan a responder a esta interpelación: "Cada lector debe llenar a partir de su experiencia propia lo que es capaz de percibir en el poema. Solo eso significa: entender un poema". ${ }^{0}$

Bien sabemos que no se trata para Gadamer de pretender una depuración de expectativas o experiencias propias para escuchar lo que un texto en general o un poema en particular dice. Pero, en cambio, sí es una tarea constante poner al servicio del poema lo que el lector sabe desde antes y, por ende, vigilar cualquier imposición indebida que amenace con violentarlo. Se requiere lo que Gadamer llama la virtud

pretendido mostrarla hasta aquí, la distinción entre un cierto adentro y un afuera del texto poético. He presentado el afuera como el significado de las palabras del poema cuando este es fijado por otras cadenas textuales distintas del poema, y el adentro, es lo que hace que las palabras signifiquen en el texto poético concreto lo que solo allí significan. El problema es que en el fondo lo que significan en el texto poético concreto es, en cierto modo, el resultado de una variación o una transformación de la significación que tienen externa al texto. Dicho de otra forma, es por contraste con lo que las palabras significan habitualmente que se logra observar de qué manera es nuevo y único el modo como significan en el poema concreto. La frontera entre un adentro y un afuera no es, pues, nítida.

29 Gadamer, ¿Quién soy yo y quién eres tú?, 153.

30 Gadamer, ¿Quién soy yo y quién eres tú?, 120. 
por excelencia del buen lector, el "tacto", para saber convocar sin perjuicio alguno para la lectura todo ese conjunto de informaciones que uno puede llegar a acumular. ${ }^{31}$ Así, por ejemplo, en su lectura de un poema titulado "Tenebrae" (Tinieblas), perteneciente a la colección Atemwende, el primer gesto de Gadamer es poner de presente todo lo que para él resuena en esa palabra: "No puede llamarse así, dice, sin evocar toda la historia de la Pasión: desde las Pasiones veterotestamentarias pasando por la Pasión neotestamentaria. Se trata de una orientación previa que debe ir aquilatándose a través del poema mismo" ${ }^{32}$ En efecto, esta primera aproximación le obliga enseguida a formular, bajo la forma de una pregunta, su hipótesis interpretativa, la cual buscará convalidar progresivamente en su lectura: “¿Es un poema blasfemo o cristiano?”. Al final, mostrará que esta disyuntiva, en la cual enmarca en un comienzo el sentido del poema, se queda corta ante lo que ha logrado extraer, pero en cualquier caso habrá sido la pregunta al hilo de la cual condujo su lectura en busca de una unidad de sentido final.

De modo similar, en su comentario a Cristal de aliento, la pregunta por el "tú", cuya figura es omnipresente en los poemas de este ciclo, es la que se ofrece a Gadamer como la línea directriz de su lectura: "Pensemos, por ejemplo, en la pregunta que planteé con motivo del ciclo de poemas Cristal de aliento: ¿Quién soy yo y quién eres tú? ¿Quién pretende contestarla? Debo insistir: la figura de ese tú es ella misma; no es este o aquel, ni una persona querida, ni el otro o ni lo del todo diferente." ${ }^{33}$ Las hipótesis sobre ese tú y ese yo no dejan de sucederse (Gadamer piensa, pero sin resolverse por ninguno, que ese tú es Dios, lo otro, el otro, yo mismo, etc.), luego de que Gadamer ha creído identificar allí un centro en torno del cual gira cada poema, "allí donde recae todo su peso", como suele decir. Sin embargo, no encontrará en el ciclo de poemas un motivo claro, unívoco, que le permita adoptar una respuesta como definitiva. El poema, dice Gadamer, no se decide, el sentido del "tú" queda indecidido. Así, después de lanzar varias hipótesis, y de intentar diferentes respuestas, termina por concluir, con gran modestia, que ninguna es finalmente concluyente: "Esta es una pregunta a la cual el poema da su propia respuesta, la deja abierta". ${ }^{34}$ Considera así que como lector le responde al poema, a su secreto último, al dejar abierta la pregunta, sin que, sin embargo, esta imposibilidad vuelva inútil la interrogación acerca de lo que el poema dice. Por el contrario, es gracias a la pregunta, previamente orientada, es verdad, pero en permanencia reabierta, que el lector llega a situarse en el horizonte abierto por el poema.

\section{Derrida, lector de Celan}

Si hago oír aquí su voz [la de Celan], si la oigo en mí, ahora, es ante todo porque comparto la admiración de Gadamer por ese otro amigo que fue Paul Celan. Como Gadamer, a menudo intenté en la noche,

31 "En última instancia, el que la identificación y el análisis de la compleja sintaxis de las connotaciones, de las cuales forman parte tales alusiones, no disuelvan ni dilaten, de tanto explayarse, la figura de sentido del discurso ni la unidad del movimiento de transposición, es una cuestión de tacto, la virtud suprema del verdadero intérprete". Gadamer, ¿Quién soy yo y quién eres tú?, 133.

32 Gadamer, "Sentido y ocultación de sentido en Paul Celan", 121.

33 Gadamer, ¿Quién soy yo y quién eres tú?, 119.

34 "Das ist eine Frage, auf die das Gedicht seine eigene Antwort dadurch gibt, daß es die Frage öffenhält"; cf. HansGeorg Gadamer, "Wer bin Ich und wer bist Du? Kommentar zu Celans gedichtfolge 'Atemkristall' (1986)", en Gesammelte Werke. Vol. 9: Ästhetik und Poetik II: Hermeneutik im Vollzug (Tubinga: Mohr Paul Siebeck, 1993$), 398$. 
leer a Paul Celan y pensar con él. Con él hacia él. Si deseo, otra vez, ir al encuentro de este poema, es en realidad para intentar dirigirme a Gadamer mismo, hablarle a él mismo fuera de mí. ${ }^{35}$

La común admiración por la obra poética de Celan brinda a Derrida la ocasión propicia para insistir más sobre lo que lo une a Gadamer que sobre lo que en vida de este se erigió entre ellos como una distancia, para algunos tan profunda, que había vuelto difícil (si acaso no imposible) poner a dialogar sus enfoques filosóficos. A primera vista, Celan se ofrece aquí como una caja de resonancia capaz de crear una armonía con las voces de ambos filósofos, en tanto la tensión producida por las distintas cuerdas que cada uno de ellos pulsa en la obra del poeta ayudaría a modular el amplio espectro de tonalidades allí contenido. Sin embargo, lo que se anuncia como un acercamiento, tardíamente reconocido quizá, pero acercamiento al fin y al cabo, entre hermenéutica y deconstrucción, se revela con rapidez como una nueva constatación del abismo que los separa en la medida en que Derrida advierte que la suya es una lectura que no pretende ser tomada en ningún caso por una interpretación de Celan, lo que, en cambio, sí es, según dice en un tono que se adivina crítico, el caso de la lectura gadameriana. Esto marcaría una fractura insalvable entre los dos ejercicios de lectura, hasta el punto de que muy pronto pierde evidencia el supuesto de que en realidad estén situados sobre el mismo suelo poético.

$\mathrm{Al}$ respecto, Derrida escribe que su lectura es "una interpretación inquieta, trémula y que hace temblar (tremblée et tremblante), quizá incluso algo totalmente distinto de una interpretación" . ${ }^{36}$ Ahora bien, con el empleo de estos adjetivos (tremblée y tremblante), el francés no sugiere, como pudiera pensarse a simple vista, un rasgo de timidez o de inseguridad que su lectura debiera reclamar para sí, por estar demasiado consciente de sus limitaciones para comprender el texto celaniano en su profundidad, renunciando, entonces, por cuenta de esta impotencia, a ser tenida como una interpretación capaz de dar, de modo penetrante, con un sentido pleno y acabado. Al revés, con tales calificativos Derrida parece aludir a todo lo opuesto, a saber: una lectura lo suficientemente potente y robusta como para celebrar y aliarse, en lugar de combatir, con la resistencia sin tregua que a todo esfuerzo comprensivo opone el texto celaniano, una lectura que renuncia a avanzar con paso seguro y, antes bien, es capaz de tomar grandes riesgos, adoptando el paso audaz de quien se lanza a la cuerda floja, superficie que se asemeja a lo que para el francés es el suelo inestable, fracturado y tembloroso del texto poético celaniano. Y esto, afirma Derrida, difiere diametralmente del gesto calculado, previsible y seguro que caracteriza a toda interpretación, incluida la gadameriana, que avanza sobre una malla de seguridad. Hay que decir que en otros lugares de su reflexión el filósofo francés ha trazado con igual énfasis una distinción equivalente, entre las que él denomina dos maneras de entender la interpretación. Así, por ejemplo, en Lécriture et la différence se refiere a "dos interpretaciones de la interpretación" ${ }^{37}$ que se sitúan en franca oposición en la medida

35 Jacques Derrida, Béliers: Le dialogue ininterrompu. Entre deux infinis, le poème (París: Galilée, 2003), 26. Para una revisión muy detallada de la presencia de Celan en el pensamiento de Derrida, véase Miriam Jerade, “To wound the Language: Derrida reads Celan", en Understanding Derrida: Understanding Modernism (Londres: Bloomsbury, 2019), 94-110, en que la autora muestra la relación estrecha entre la preocupación de Derrida por pensar la alteridad en su carácter radical, eje principal de su filosofía, y el interés que lo lleva a ocuparse de la obra de Celan, en que el filósofo francés advierte un lenguaje inventivo, portador de una profunda herida, una cicatriz, una suerte de alteridad intraducible que, sin embargo, encuentra su idioma singular en el poema.

36 Derrida, Béliers, 26 [cursivas mías].

37 "Il y a donc deux interprétations de l'interprétation, de la structure, du signe et du jeu. L'une cherche à déchiffrer, rêve de déchiffrer une vérité ou une origine échappant au jeu et à l'ordre du signe, et vit comme un exil la nécessité de l'interprétation. L'autre qui n’est plus tourné vers l'origine, affirme le jeu et tente de passer au-delà de l'homme 
en que aquella que, según deja entender, aunque sin nombrarla explícitamente así, corresponde a la hermenéutica, afirma la existencia de un sentido que dirige, más allá del juego de signos, el movimiento interno de estos en el texto, de modo que es en pos de este sentido extra-textual hacia donde busca orientarse el esfuerzo interpretativo; esta manera de interpretar, juzga Derrida, se reduce a un simple ejercicio de desciframiento. En contraste, la otra manera de interpretar, que Derrida identifica con la practicada por él bajo la forma de la deconstrucción, se libraría al mismo juego, pero sin imponerle restricción alguna, con la alegría y el coraje de un espíritu errante, consciente de la imposibilidad intrínseca de delimitar el juego de significantes por un sentido que permaneciera fuera del juego: un "significado trascendental".

Para Derrida, en efecto, en la medida en que toda interpretación opera sobre el principio hermenéutico de "unidad de sentido" del texto, constituye un tipo de lectura al cual la suya no busca en lo absoluto plegarse. Por el contrario, si algo caracteriza su modo de acercarse a la escritura poética de Celan, es, precisamente, su interés por, como él mismo afirma, "erradicar" tal principio de lectura ${ }^{38}$ Así, en Béliers, cuando Derrida distingue entre una lectura hermenéutica y una lectura-escritura diseminal, de modo que es esta última la figura bajo la cual sitúa el ejercicio que él mismo emprende, se refiere a una frontera infranqueable entre ambas, frontera que, sin embargo, sería traspasada con bastante frecuencia. Ciertamente, cuanto más advirtamos la naturaleza de la distancia que las separa, más claro se volverá para nosotros que la distinción entre lectura hermenéutica o interpretativa, por un lado, y lectura-escritura diseminal, por otro, no puede ser reducida a una mera oposición frontal entre ambas, de tal forma que los rasgos que distinguen positivamente a la una fueran, simétricamente vistos, los mismos de los que la otra carece. La relación entre las dos formas de lectura obedece a un vínculo más complejo e imbricado, totalmente asimétrico, en la medida en que, como veremos, existe cierta dependencia que convierte a una de ellas en condición de posibilidad de la otra. Esto implica que no tienen lugar en un mismo nivel, que una solo puede ocurrir a espaldas de la otra y, a la vez, que las dos son posibles de forma simultánea. De modo que el anuncio de Derrida de "erradicar el principio hermenéutico", aunque indudablemente parece tener el tono de una confrontación, en realidad no da lugar a una disputa entre dos alternativas de lectura, como lo sugiere la formulación, es decir, no entraña nada parecido a un conflicto de interpretaciones.

De acuerdo con Derrida, a la lectura hermenéutica la distingue un enfoque formal, politemático, atento a los pliegues del sentido. Se refiere con esto a que el intérprete se concentra en desplegar el texto de modo que no quede nada oculto o indescifrable, esto es, busca exponerlo a una mirada abarcadora y englobante capaz de identificar en él un sentido plenamente presente y sin vacíos. Esta lectura detiene así su atención en aquellos quiebres que amenazan la lisura del texto y se aventura a dar con el sentido que ocultan, el cual debe probar estar en arreglo a la unidad presumida del texto. Y si bien la lectura diseminal no ignora simplemente a esta otra lectura, pues, según el francés, puede eventualmente servirse de sus métodos formales y de su proceder interpretativo, algo las separa de forma radical, hasta el punto de hacerlas incompatibles. Lo que las separa tiene que ver con que la lectura diseminal responde a algo que excede

et de l'humanisme, le nom de l'homme étant le nom de cet être qui, à travers l'histoire de la métaphysique ou de l'onto-théologie, c'est-à-dire du tout de son histoire, a rêvé la présence pleine, le fondement rassurant, l'origine et la fin du jeu". Jacques Derrida, "La structure, le signe et le jeu”, en Lécriture et la différence (París: Seuil, 1967), 427 [cursivas mías].

38 "Éradication du principe herméneutique. Il n’y a pas un sens dès qu'il y a de la date et schibboleth, plus en seul sens originaire". Jacques Derrida, Schibboleth pour Paul Celan (París: Galilée, 1986), 50. 
absolutamente a la lectura hermenéutica, algo que Derrida llama un "resto" o "excedente irreductible". ¿Irreductible a qué? Claro está, al principio hermenéutico de la unidad de sentido. Para Derrida, si la hermenéutica no va tan lejos como puede hacerlo la lectura-escritura diseminal, es porque, a diferencia de la primera, la segunda "se dirige hacia un resto o un excedente irreductible. El exceso de este resto se sustrae a toda reunión en una hermenéutica". ${ }^{39}$

Visto así, este resto llevaría a pensar en lo que escapa a la pretensión hermenéutica de clausurar el texto poético bajo un sentido unitario y total, y señalaría, por ende, un lugar de indecidibilidad, que, precisamente en tanto tal, obliga a inhibir la posibilidad de decisión por parte del lector entre las alternativas abiertas por sus hipótesis interpretativas; un lugar que, pese a los esfuerzos comprensivos del intérprete, permanece sin coordenadas fijas, pero del que se sabe, al menos, que ocupa un sitio, aunque haya de ser marcado con una equis en el plano extendido y abierto de sentido; un lugar, en fin, para determinar que el lector no cuenta, sin embargo, con ningún punto de referencia absoluto. La lectura hermenéutica, ciertamente, puede dar lugar a un resto así. De hecho, cuando Gadamer reconoce la imposibilidad de dar un sentido pleno a un poema de Celan, cuando admite, por ejemplo, que su deber como lector es dejar abierta la pregunta que se formula en su comentario acerca de quién es el "tú" al cual se estarían refiriendo los poemas celanianos y al dejar, por tanto, en suspenso el trabajo interpretativo, a falta de evidencias que lo lleven a decidirse plenamente por una hipótesis más que por otra, allí su lectura estaría dando claras muestras de sensibilidad frente a una indecidibilidad así, frente a ese resto hermenéutico, si queremos bautizarlo de algún modo. Pero no es a este resto al que se refiere Derrida.

El filósofo francés advierte que el resto en respuesta al cual avanza la lectura-escritura diseminal no debe ser entendido de este modo secundario, es decir, como algo que resulta de la lectura hermenéutica y de su fracaso en constatar el principio de unidad, un cierto excedente a posteriori (si se me permite el abuso del término) que solo se descubre luego del intento fallido por integrarlo sin fricción en la lógica de sentido puesta en marcha previamente por el intérprete; este es un residuo producido por la lectura hermenéutica, mientras que el resto que la lectura diseminal persigue sería en cierto modo a priori, es decir, uno que antecede y hace posible, sin ser objeto para ella, de la lectura interpretativa. Por esta razón, el de Gadamer le parece un gesto admirable, sin duda, por cuanto responde con honestidad a lo que de refractario hay en el texto, pero, en realidad, se le revela profundamente tímido y limitado cuando se trata de atender a un resto que se adivina más radical, más irresoluble, menos domeñable.

Ciertamente, cuando el francés deja saber su insatisfacción frente a la lectura gadameriana, con todo y que reconoce la capacidad que esta tiene de dejar callar al poema, y así inhibir cualquier "tentación por saturar, incluso sobrecargar de discursos virtuales, de significación o meditaciones sin fin”, ${ }^{40}$ parece reclamarle por su falta de riesgo, por lo que él denomina "su sumisión al orden de lo calculable y lo decidible". ${ }^{41}$ En realidad, allí donde Gadamer se detiene en su empeño interpretativo, reconociendo una ruptura de sentido que le impide avanzar, por no encontrar razones determinantes para retener una hipótesis y desechar otra; allí donde, por ende, él se ve obligado a inhibir su juicio dejándolo suspendido a manera de una pregunta abierta (¿Quién es, pues, ese tú? El poema calla), tal ruptura se revela para

39 Derrida, Béliers, 47.

40 Derrida, Béliers, 44.

41 Derrida, Béliers, 54. 
Derrida como de carácter superficial. Y esto porque tal interrupción sucede sobre un trasfondo de continuidad que termina por atenuarla o, todavía más, por incorporarla al espacio infinitamente abierto de lo comprensible. En efecto, la lectura hermenéutica, dice Derrida, "avanza de sentido en sentido, de verdad en verdad". Es al hilo de esta continuidad que la pregunta es formulada, ya que, aunque el lector no pueda con certeza decidir si lo que dice el texto es esto o aquello, lo que su pregunta deja indeciso presupone algún modo de "es", es decir, la ruptura de sentido que instaura el "o" (recordemos que según Gadamer toda pregunta tiene la forma lógica del “es esto así o no es así?”), adopta la forma de una fractura relativa a un así o de otro modo.

Según Derrida, el trabajo de la hermenéutica es el de un desciframiento que avanza al hilo de un sentido que se deshilvana sin fin, un sentido afirmado como infinito solo para darse mejores motivos para perseguir su despliegue inagotable. "Más que la indecisión misma, admiro el respecto marcado por Gadamer en el lugar de una indecisión. Esta parece interrumpir o suspender el desciframiento de la lectura, pero en realidad asegura su porvenir". ${ }^{42}$ Su principio es, pues, el de la inagotabilidad del sentido, no el de su imposibilidad. Dicho de otro modo, la indecidibilidad con la cual juega la hermenéutica se parece a la que admite la estadística, que, a falta de disponer de todas las variables, integra en su fórmula lo que llama un "margen de error", espacio para lo desconocido que se contenta con nombrar en la ecuación con el vago signo de una $x$. Se atribuye a lo incalculable una función dentro del cálculo, y así se termina por neutralizarlo, es decir, por integrarlo en la ley de lo calculable.

De hecho, Derrida sugiere una distinción entre "incalculable" y "no calculable" para distinguir justamente entre lo que es derivado del cálculo, como una especie de residuo no dominado, y lo que, por principio, se mantiene extraño a todo cálculo y que, todavía más, lo hace posible. El primero es un resto que sobreviene después de haber puesto a prueba un proyecto de sentido, es un resto respecto del pasado. Derrida, por su parte, habla de un resto por venir y, por ende, productivo, no residual. Ocurre así que en la hermenéutica, según Derrida, si se afirma lo indecidible, se lo hace en función de lo decidible. Tal indecidibilidad (calculable) sería el resultado de un esfuerzo repetido de decisión que se revela finito frente al carácter no agotable de su objeto. Por esta razón, la hermenéutica termina por atribuir a lo indecidible el estatuto de un sentido puramente residual.

En realidad, insiste Derrida, la ley del sentido no se habría roto de ninguna manera; más aún, la hermenéutica no puede romperla, pues, por el contrario, es gracias a esta ley, a la cual está sujeta, que su trabajo de desciframiento se hace posible. ${ }^{43}$ Tan pronto como en un diálogo una palabra llama a otra, lo que se teje entre ellas es una continuidad de sentido que olvida su interrupción inicial. Es este rasgo de la continuidad, situado en el corazón de la anticipación hermenéutica del sentido, el que Derrida cuestiona en su confrontación con Gadamer. En últimas, aquello sobre lo cual Derrida parece dudar es sobre la posibilidad de llegar, a través del diálogo, a dar un paso atrás de lo decidible, ya que desde que se plantea una pregunta uno se encuentra ya atrapado en ese juego, es decir, en la continuidad de sentido. La pregunta sería un punto de inflexión en la curva zigzagueante, pero en todo caso continua, de la comprensión de sentido. La hermenéutica, insiste Derrida, no opera el gesto arriesgado que, por su parte, reclama la lectura deconstructiva, que no es tanto escapar de esa ley, pero al menos volverla ineficaz.

42 Derrida, Béliers, 37.

43 "Sans ce risque, sans cette improbabilité, sans cette impossibilité de prouver qui doit demeurer à l'infini et qui ne doit pas être, elle, saturée ou fermée par une certitude, il n’y aurait ni lecture, ni don, ni bénédiction”. Derrida, Beliers, 35-36. 
La lectura-escritura diseminal estaría movida por un sentimiento de pérdida más profundo, en tanto considera que existe una discontinuidad irrecuperable en el texto, un sinsentido absoluto que lo atraviesa, un resto radicalmente otro, que no después del intento comprensivo, sino desde antes, desde siempre y para siempre, impide cualquier epifanía de sentido a la manera a la que aspira la hermenéutica. Una indecidibilidad, si se quiere, absolutamente indecibible, por cuanto su modo de ser escapa a la lógica misma de la decisión, esto es, a la disyuntiva del "así o más bien así", y parece acomodarse mejor a la forma completamente negativa del "ni (así)... ni (así)". Escribe Derrida: "En contraste, la experiencia diseminal toma y asume la prueba de una interrupción, marca en el poema, el hiato de una herida cuyos labios no se cierran o no se juntan nunca" (p. 54). La imagen de estos labios dolorosamente entreabiertos de la que Derrida se sirve para referirse al poema celaniano sugiere, en efecto, una palabra que busca ser pronunciada, pero que no llega nunca a articularse, unos labios que a pesar de su apertura se quedan mudos, de modo que es la suya una apertura que, en realidad, no abre sentido alguno, sino que se cierra a él. Podría uno decir que, mientras en la lectura hermenéutica prima un cierto tinte optimista, al concebir ese resto como infinitamente abierto, aunque también infinitamente suspendido, esto es, mientras confía en la capacidad de la lectura de restañar eventualmente y en cierto grado esa herida de sinsentido, el lector que practica esta otra lectura se mantiene, en cambio, fiel a lo incurable de la herida.

La distinción entre la lectura hermenéutica y la lectura-escritura diseminal es presentada por Derrida bajo la forma de una oposición entre una lectura que atiende a una ruptura externa al texto, en contra de una lectura que, por su parte, sigue el curso de una ruptura interna. Tal ruptura externa lo rodea y lo limita por fuera, en tanto la interna, dice el francés, atraviesa el texto desde dentro suyo, y lo desteje en sus propias entrañas. La lectura hermenéutica es sensible a la ruptura externa que desde un cierto "afuera del texto" busca delimitarlo y darle forma, es decir, le confiere una unidad, mientras que la lectura diseminal responde a aquella ruptura que, por serle íntima, le impide al texto albergar cualquier pretensión de unidad e identidad definitivas. Antes bien, sabotea cualquier pretensión o atribución de unidad e identidad que se quiera atribuir al texto. Pero, entonces, ¿a qué se refiere ese resto, ese otro, que por serle interior es tanto más radical y originario (su textualidad misma), ese resto al que dice responder la lectura derridiana? "La restance de este resto, escribe Derrida, es lo que nos hace para nosotros, legible e ilegible simultáneamente, el poema". ${ }^{4}$

No hay duda de que esta formulación, como tantas otras con las que Derrida nos sorprende, nos inmoviliza por lo que tiene de aporético, en la medida en que solemos entender legibilidad e ilegibilidad como rasgos opuestos que, como tales, no parecen poder ser afirmados simultáneamente respecto del mismo texto, sin entrar de inmediato en contradicción. O bien un texto es legible, pensamos, y entonces está escrito de tal forma que su sentido es susceptible de ser comprendido por quien sabe descifrar su escritura, $o$ bien es ilegible, y entonces adolece de un problema constitutivo que pone en cuestión su estatuto como texto, ya que no llega a revelarse conforme a las reglas de la buena escritura que lo hacen descifrable para quien sepa leer. Ahora bien, Derrida sostiene, como vemos, que la legilibilidad y la ilegibilidad son algo así como dos realidades simultáneas de todo texto en la medida en que aquello que lo hace legible es al tiempo lo que lo hace ilegible. ¿Cómo entenderlo?

Si la legibilidad tiene que ver con la organización que exhibe un texto (una cierta "economía textual”) en torno a un centro desde el cual se irradia orden al resto de sus partes, integrándolas a todas en una unidad

44 Derrida, Béliers, 48. 
de sentido más o menos acabada, cuya inteligibilidad obedece a una ley susceptible de ser expuesta, la ilegibilidad, por su parte, tendría que ver con la ausencia de un centro fijo en función del cual hacer comparecer el orden englobante en el que entran sus partes. Pero, entonces, no parece que avancemos mucho en lidiar con esta contradicción, porque no es fácil entender que un texto esté centrado y a la vez descentrado, que sea legible y simultáneamente ilegible. Ahora bien, la ausencia de un centro que aglutine y dé unidad al conjunto del texto no se reduce a afirmar el fracaso del texto, a pesar suyo o del autor, en ese empeño económico y, por ende, que esto dé lugar a varios centros posibles, de tal modo que, al no poder ninguno de ellos asumir plenamente como dicho centro absolutamente gobernante, cada uno se desvirtúa como tal y el texto se desarticula. Lo que quiero decir es que la ilegibilidad de la que Derrida habla no es un problema de índole empírica, reductible a la ausencia de un centro o a la presencia de muchos centros posibles, en cuyo caso podría ser entendido como un defecto susceptible de reparación o de corrección con el recurso a una buena técnica de escritura. La ilegibilidad a la que se refiere constituye una condición inherente a todo texto posible, condición gracias a la cual se hace legible.

En efecto, aquello que permite producir esa economía textual por la que el sentido gravita y se unifica en torno a un centro, es precisamente el mismo des-centramiento primordial del texto, es decir, lo que en él se rehúsa a ser fijado bajo ley alguna y, no obstante, gobierna el texto, recorriéndolo con su energía configurativa pero también disruptiva, llevándole a con-centrarse aquí o allá, y a deshacer tal orden. En otros momentos de sus escritos, Derrida se refiere a ello como "juego de diferencias", juego que él mismo no se hace presente en ningún lugar del texto, pero que como efecto suyo hace posible toda forma de presencia, todo centro, un juego que dispersa o multiplica sus efectos, organizando y desorganizando el texto. Es, pues, a ese juego, a esa différance, al que, en su lectura de Celan, Derrida se refiere como resto. Es el que hace al texto radicalmente ilegible en la medida en que constituye lo que es absolutamente inapropiable del texto bajo el principio de unidad de sentido, no es ni esto ni aquello, en el fondo, no "es" o es "nada". Pero también es lo que explica la legibilidad que persigue la lectura interpretativa. Legibilidad e ilegibilidad del texto poético son efectos simultáneos y no contradictorios del resto, ya que de ninguna manera se oponen una a la otra, sino que se despliegan al tiempo. Lo radicalmente ilegible no se opone a lo legible, ya que uno y otro no están, por así decir, situados en el mismo nivel, no se oponen respecto de un mismo atributo del texto como sería su plenitud de sentido. La ilegibilidad hace posible la legibilidad, la legibilidad transcurre siempre sobre un fondo de ilegibilidad. El problema surge, sin embargo, cuando se olvida, por así decir, que lo legible se debe a lo ilegible, cuando el centro es erigido como un centro absoluto y se ignora lo que en el texto mismo resiste a ponerse bajo su reinado. En tal caso, es preciso darse a la tarea de erradicar el principio de unidad de sentido que lo considera legible.

Lo ilegible del poema o, mejor, su ilegibilidad, lejos de ser un accidente, de mayor o menor gravedad, imputable a una mala escritura que con su defecto compromete la fluidez de la lectura, es, en cambio, lo que constituye el texto como tal; es su textualidad misma lo que hace al texto ilegible. Mientras la lectura hermenéutica solo puede ser sensible al tipo de ilegibilidad que es corregible o reparable, en la medida en que cree que la escritura puede afinar su capacidad para reenviar con cierta univocidad a un sentido que lo excede y lo determina desde fuera, la lectura-escritura diseminal atiende, por su lado, a eso que de radicalmente ilegible el texto porta consigo. Para esta lectura, lo indescifrable del poema no tiene que ver con nada que permanezca oculto en él, con una presencia ausente, sino, antes bien, con una ausencia que stricto sensu no lo es, ya que la ausencia alude de inmediato a un modo negativo de la presencia. Esta, en cambio, es una ausencia que llamaríamos pura y que no es el propósito de la lectura exponer o sacar de su ocultamiento. Derrida habla, precisamente, de este resto como de una "huella" (trace), cuyo modo de ser no se deja reducir ni a una forma de presencia ni de ausencia, que por tanto excede y vuelve caduca 
esta oposición binaria. De modo que, si en el caso de la lectura interpretativa el fracaso que experimenta el intérprete obedece a lo que él mismo entiende como su incapacidad para exponer lo que el texto no alcanza a mostrar, en el segundo caso, el fracaso estaría en querer mostrar o descifrar como presencia lo que es inmostrable, impresentable, olvidado. Y si este resto, contrario a lo que pudiera pensarse, no constituye propiamente una amenaza para la lectura hermenéutica, de tal forma que le impidiera avanzar con la seguridad que pretende, de sentido en sentido y de verdad en verdad, hasta tropezar con una apertura de sentido indecidible, se debe a que para Derrida este resto es el que hace posible tal lectura en la medida en que constituye el llamado que el poema dirige al lector que busca comprenderlo. Podríamos decir que este resto, esto totalmente otro, es lo que detiene al lector en primer lugar, lo que lo retiene en el texto y en esa medida lo llama a comprenderlo y a hacerlo legible. Si la lectura de Derrida es vista, por lo general, como ex-céntrica, en lo cual muchos han querido ver cierta arbitrariedad o violencia ejercida sobre los textos, pretendidamente organizados según una economía más rígida, más evidente, llamada a ser comprendida, descifrada y expuesta en su plenitud, es por cuenta de esa sensibilidad de su lectura al resto ilegible que todo texto porta consigo, por cuenta del oído que presta a lo que se anuncia como otro.

Este resto es lo que él también llama schibboleth del poema, "schibboleth que se expone y se oculta a nosotros". ${ }^{45}$ Cuando en su libro Schibboleth pour Paul Celan, de 1984, Derrida se ocupa a su turno de presentar su propia lectura de la obra del poeta, insiste permanentemente en que se trata, para él, de atender a lo ilegible del poema, de escuchar lo que en él ofrece una resistencia inveterada a la lectura interpretativa. Su propósito es hacer justicia al enigma. Y la fecha es uno de esos enigmas en los poemas de Celan. En efecto, este es un tema sobre el que el poeta reflexiona en algunos de sus discursos, pero, sobre todo, él se libra en sus poemas a inscribir fechas, a datar aniversarios, acontecimientos, etc., fechas que Derrida llama ilegibles. Escribe al respecto: "[la fecha] parece resistirse a toda pregunta, a toda forma de cuestionamiento filosófico, a toda objetivación, a toda teorización teórico-hermenéutica” ${ }^{46}$ ¿Cómo leer entonces la fecha en Celan? ¿Es acaso posible? La pregunta, que a primera vista sorprende, se vuelve apremiante cuando Derrida advierte que datar algo es de hecho imposible, porque lo fechado, que es irrepetible y único, algo que ocurre una sola vez, al ser datado se anula en su sola vez, esto es, borra su singularidad, pues el solo hecho de datarlo lo "inscribe" ya en un movimiento de repetición y de vuelta. Para marcar un acontecimiento único e irrepetible, toda fecha debe, a la vez, des-marcarse de él. "Una sola vez" tiene la estructura paradójica de un "a la vez" o de un "a la vuelta"; "una vez", cierto, es un "[a la vez] con otra vez". Lo legible de una fecha es, precisamente, lo que se repite, pero la legibilidad de la fecha como tal obliga a que lo irrepetible de lo fechado deba ser pasado por alto o, mejor, exige que lo fechado sea ilegible. La legibilidad de la fecha está así íntimamente ligada a su fuerza de autoanulación, esto es, a lo que en ella se sustrae y es radicalmente ilegible. La lectura derridiana se entrega así al enigma de la fecha en Celan, renuncia a descifrarlo y da más bien cuenta (testimonio) de su carácter indescifrablemente enigmático.

45 Derrida, Béliers, 49. “Término atravesado por una multiplicidad de significados: río ribera, espiga de trigo, ramo de olivo. Pero más allá de todos esos valores, ha tomado el de contraseña. Se la utilizó durante y después de la guerra en el paso de una frontera vigilada. La palabra importaba menos por su sentido que por la manera como era pronunciada. La relación con el sentido o con la cosa se encuentra suspendido, neutralizado, puesto entre paréntesis: lo contrario, si cabe decir, de una 'epojé' fenomenológica que guarda en primer lugar el sentido". Derrida, Schibboleth pour Paul Celan, 44.

46 Derrida, Schibboleth pour Paul Celan, 17. 


\section{Bibliografía}

Adorno, Theodor W. Teoría estética. Madrid: Taurus, 1980.

Caner-Liese, Robert. Gadamer, lector de Celan. Barcelona: Herder, 2009.

Derrida, Jacques. De la grammatologie. París: Éditions de Minuit, 1967.

Derrida, Jacques. "La structure, le signe et le jeu”. En L’écriture et la différence, 409-428. París: Seuil, 1967.

Derrida, Jacques. Béliers: Le dialogue ininterrompu. Entre deux infinis, le poème. París: Galilée, 2003.

Derrida, Jacques. Schibboleth pour Paul Celan. París: Galilée, 1986.

Dutt, Carsten. Herméneutique, esthétique, philosophie pratique: Dialogue avec Hans-Georg Gadamer. Québec: Les Editions Fides, 1998.

France-Lanord, Hadrien. Paul Celan et Martin Heidegger: Le sens d’un dialogue. París: Fayard, 2004.

Gadamer, Hans-Georg. ¿Quién soy yo y quién eres tú? Comentario a "Cristal de aliento" de Paul Celan. Barcelona: Herder, 2001.

Gadamer, Hans-Georg. Poema y diálogo. Barcelona: Gedisa, 2004.

Gadamer, Hans-Georg. Gesammelte Werke. Vol. 9: Ästhetik und Poetik II: Hermeneutik im Vollzug. Tubinga: Mohr Paul Siebeck, 1993.

Jerade, Miriam. “To wound the Language: Derrida reads Celan". En Understanding Derrida: Understanding Modernism, 94-110. Londres: Bloomsbury, 2019.

Oyarzún, Pablo. Entre Celan y Heidegger. Santiago de Chile: Metales Pesados, 2013.

Szondi, Peter. Estudios sobre Celan. Madrid: Trotta, 2005.

Vega, Amador. Tres poetas del exceso: La hermenéutica imposible en Eckhardt, Silesius y Celan. Barcelona: Fragmenta, 2011.

Zamora, José A. “Estética del horror: Negatividad y representación después de Auschwitz”. Isegoría 23 (2000): 183196. 